\title{
37. HEAVY-MINERAL ANALYSIS OF SEDIMENTS FROM THE DEEP SEA DRILLING PROJECT TRANSECT OF THE JAPAN TRENCH, LEGS 56 AND 57
}

\author{
Takashi Miki and Ryohei Takahashi, Department of Geology, Kyushu University, Fukuoka, Japan
}

\begin{abstract}
Heavy-mineral assemblages in the cored sediments from DSDP Legs 56 and 57 show a distinct change of source rocks, from older sedimentary rocks during the Oligocene to volcanic rocks during the Miocene through Pleistocene. The former might have been supplied by the "Oyashio ancient landmass," and the latter from the volcanic areas in Hokkaido and northeast Honshu. This indicates a shift of the Japanese Islands toward the continent.
\end{abstract}

\section{INTRODUCTION}

During Legs 56 and 57, sediments were cored in 16 bore holes at 7 sites across the Japan Trench east of Hokkaido and northeast Honshu; many samples from the Cretaceous to the Pleistocene were obtained.

We investigated the heavy-mineral assemblages of 59 samples of sandy and silty sediments from these holes. The main purpose was to identify the source rocks of these sediments and to supply basic data for geologic research in and around the Japan Trench.

The present report includes our results and interpretations, but we could not perform a detailed analysis because of an insufficient number of samples.

\section{MATERIALS AND EXPERIMENTAL PROCEDURE}

We received 65 samples of sand, sandy silt, silt, sandstone, and siltstone, from which we chose 59 for analysis after megascopic examination and elimination of some unsuitable samples.

Samples from Holes 434 and 435 are Pliocene to Pleistocene; those from Hole 439 are upper Oligocene to lower Miocene; those from Hole 438B are lower to middle Miocene; others are upper Miocene to Pleistocene. (See site chapters, this volume.)

We used the methods of Miki (1972). We gently crushed each sample until all grains passed through a 60 -mesh sieve $(0.25$-mm opening). After removing and dissolving clayey matter and carbonates by cleaning with water and heating for 15 minutes with dilute (1:1) $\mathrm{HCl}$ on a water bath, we separated heavy minerals from other constituents with Thoulet's solution, a heavy liquid with a specific gravity of 2.87 .

Some materials are illustrated in Plates 1 and 2.

\section{RESULTS}

Weight percentages of heavy residues vary remarkably from 0.01 to 10.71 per cent (Table 1 ).

The majority of the Oligocene-Miocene samples con- tain less than 1 per cent heavy minerals; younger sediments contain more.

Non-opaque heavy minerals are hypersthene, augite, diopside, brown hornblende, green hornblende, epidote, mica, zircon, garnet, tourmaline, glauconite, and sphene, as indicated in Table 1 . Glauconite, ${ }^{1}$ an authigenic mineral, occurs rarely in some samples. Oxyhornblende, which is lumped with brown hornblende in the table, also appears.

High concentrations of mafic minerals such as pyroxene and amphibole, most of which are euhedral, are characteristic of the Miocene to Pleistocene assemblage. The Oligocene samples from Site 439 are, on the other hand, characterized by a rather high frequency of stable minerals such as zircon, garnet, and tourmaline.

Frequency of hypersthene shows striking variations, from 0 in the Oligocene to 81.9 per cent in the Pliocene, and total pyroxenes, including augite and diopside varies from 4.1 to 91.0 per cent. Frequency of hornblende, another characteristic mineral in the Neogene and the Quaternary, is 6.0 per cent at minimum and 93.3 per cent at maximum.

In the upper-Oligocene to lower-Miocene samples from Site 439, the frequency of pyroxene varies inversely with that of zircon, garnet, and tourmaline. The small elongation ratio of zircon (mostly less than 2.0) indicates not a volcanic but a sedimentary source (Poldervaart, 1955). The maximum frequency of zircon is $\mathbf{5 2 . 0}$ per cent; that of garnet is 39.7 per cent; and that of tourmaline is 2.9 per cent.

Mineral frequencies were recalculated and plotted on a triangular diagram, in which pyroxene, hornblende, and zircon plus garnet plus tourmaline are the end members. Neogene to Quaternary samples plot mostly on and near the pyroxene-hornblende line, and Oligocene samples plot away from it (Figure 1).

\footnotetext{
${ }^{1}$ Most galuconite grains whose specific gravity is a little less than that of the heavy liquid might be removed together with light minerals during separation.
} 
TABLE 1

Heavy-Mineral Analysis

\begin{tabular}{|c|c|c|c|c|c|c|c|c|c|c|c|c|c|}
\hline \multirow[b]{2}{*}{$\begin{array}{c}\text { Sample } \\
\text { (Interval in } \mathrm{cm} \text { ) }\end{array}$} & \multirow[b]{2}{*}{$\begin{array}{l}\text { Heavy } \\
\text { Residue }^{\mathrm{a}} \\
\text { (wt. \%) }\end{array}$} & \multicolumn{12}{|c|}{ Non-Opaque Heavy Minerals (frequency \%) } \\
\hline & & $\begin{array}{l}\text { Hyper- } \\
\text { sthene }\end{array}$ & Augite & $\begin{array}{l}\text { Diop- } \\
\text { side }\end{array}$ & $\begin{array}{l}\text { Brown } \\
\text { Horn- } \\
\text { blende }\end{array}$ & $\begin{array}{c}\text { Green } \\
\text { Hornblende }\end{array}$ & $\begin{array}{l}\text { Epi- } \\
\text { dote }\end{array}$ & Mica & Zircon & Garnet & $\begin{array}{l}\text { Glauco- } \\
\text { nite }\end{array}$ & Sphene & $\begin{array}{l}\text { Tour- } \\
\text { maline }\end{array}$ \\
\hline $434-1-1,121-123$ & 0.26 & 27.2 & 26.3 & 6.8 & 12.6 & 15.5 & 6.8 & 2.9 & 1.9 & - & - & - & - \\
\hline $5-1$ & 1.30 & 22.7 & 29.7 & 4.5 & 13.6 & 22.7 & 4.5 & 2.3 & - & - & - & - & - \\
\hline $15-1,32-34$ & 1.07 & 25.9 & 35.2 & 3.4 & 6.9 & 20.7 & 3.4 & 0.9 & 0.9 & 0.9 & 0.9 & 0.9 & - \\
\hline $15-2,42-44$ & 1.73 & 28.8 & 18.6 & 3.4 & 16.9 & 26.5 & 2.5 & 0.8 & 2.5 & - & - & - & - \\
\hline $19-1,17-19$ & 0.58 & 26.7 & 20.0 & 3.3 & 13.3 & 26.7 & 3.3 & 6.7 & - & - & - & - & - \\
\hline $25-1,43-45$ & 0.29 & 56.8 & 21.6 & 0.9 & 4.5 & 12.6 & 1.8 & - & - & - & 0.9 & 0.9 & - \\
\hline $25-2,60-62$ & 10.71 & 81.9 & 9.1 & - & 3.0 & 3.0 & 3.0 & - & - & - & - & - & - \\
\hline $435-5-4,57-59$ & 1.77 & 37.2 & 31.4 & 4.3 & 5.7 & 17.1 & 2.9 & 1.4 & - & - & - & - & - \\
\hline $7-3,70-71$ & 2.88 & 55.4 & 24.0 & - & 5.8 & 14.0 & 0.8 & - & - & - & - & - & - \\
\hline $8-2,12-14$ & 8.20 & 54.0 & 21.7 & - & 11.3 & 11.3 & 1.7 & - & - & - & - & - & - \\
\hline $9-3,86-88$ & 5.35 & 52.3 & 31.4 & - & 4.8 & 10.5 & - & - & 1.0 & - & - & - & - \\
\hline $12-1,23-25$ & 2.54 & 57.3 & 24.8 & - & 4.0 & 12.9 & 1.0 & - & - & - & - & - & - \\
\hline $438-1-1,17-19$ & 2.87 & 42.2 & 39.4 & 4.6 & 3.7 & 10.0 & - & - & - & - & - & - & - \\
\hline $1-2,66-68$ & 3.42 & 31.4 & 33.8 & 1.7 & 9.9 & 20.7 & 2.5 & - & - & - & - & - & - \\
\hline $8-3,16-18$ & 0.30 & 33.0 & 26.8 & - & 12.2 & 23.2 & 1.2 & 1.2 & - & 1.2 & 1.2 & - & - \\
\hline $9-1,45-47$ & 0.07 & 23.3 & 24.3 & 1.2 & 16.3 & 23.3 & 3.5 & 2.3 & 2.3 & 1.2 & 2.3 & - & - \\
\hline $10-4,84-86$ & 0.39 & 28.5 & 17.9 & 3.6 & 21.4 & 23.2 & 1.8 & - & 1.8 & 1.8 & - & - & - \\
\hline $11-5,6-8$ & 5.28 & 41.7 & 38.3 & 1.7 & 5.2 & 9.6 & 2.6 & - & 0.9 & - & - & - & - \\
\hline $138 \mathrm{~A}-1-1,120-122$ & 3.36 & 38.6 & 34.5 & - & 14.3 & - & 11.8 & 0.8 & - & - & - & - & - \\
\hline $3-6,49-51$ & 5.86 & 38.1 & 27.6 & - & 16.6 & 17.7 & - & - & - & - & - & - & - \\
\hline $4-5,148-150$ & 7.02 & 46.4 & 34.9 & 0.9 & 7.5 & 9.4 & 0.9 & - & - & - & - & - & - \\
\hline $6-2,43-45$ & 0.10 & 14.0 & 23.3 & - & 32.5 & 25.6 & 2.3 & - & - & 2.3 & - & - & - \\
\hline $26-3,44-46$ & 0.05 & 7.1 & 17.9 & - & 39.3 & 17.9 & 3.6 & - & 7.1 & 7.1 & - & - & - \\
\hline $42-3,115-117$ & 1.27 & 41.7 & 36.6 & - & - & 21.7 & - & - & - & - & - & - & - \\
\hline 438B-8-1, 102-105 & 0.02 & 7.1 & 43.0 & 7.1 & 21.4 & 14.3 & - & - & 7.1 & - & - & - & - \\
\hline $9-1,61-63$ & 0.72 & 22.4 & 13.8 & - & 3.4 & 58.7 & 1.7 & - & - & - & - & - & - \\
\hline $19-3,124-126$ & 0.19 & 4.8 & 14.3 & - & 23.8 & 47.6 & - & - & 9.5 & - & - & - & - \\
\hline $20-5,37-39$ & 0.29 & 19.0 & 6.3 & - & 35.4 & 36.8 & 2.5 & - & - & - & - & - & - \\
\hline $439-15-3,71-73$ & 0.47 & - & 36.8 & - & 15.8 & 36.8 & 5.3 & - & 5.3 & - & - & - & - \\
\hline $21-1,97-99$ & 2.82 & 10.3 & 23.7 & - & 23.7 & 35.1 & 5.2 & - & - & 1.0 & - & - & 1.0 \\
\hline $21-2,107-109$ & 0.94 & 7.4 & 18.5 & - & 18.5 & 51.9 & - & - & 3.7 & - & - & - & - \\
\hline $22-2$ & 0.28 & 10.5 & 26.3 & 1.8 & 19.3 & 28.0 & 1.8 & - & 3.5 & 7.0 & - & - & 1.8 \\
\hline $22-3,133-135$ & 0.26 & - & 36.7 & - & 26.7 & 33.3 & - & - & 3.3 & - & - & - & - \\
\hline $23-1,31-32$ & 0.19 & 4.3 & 31.4 & 1.4 & 11.4 & 38.6 & - & - & 10.0 & 2.9 & - & - & - \\
\hline $23-3,8-10$ & 0.18 & - & 27.3 & - & 22.7 & 45.5 & 4.5 & - & - & - & - & - & - \\
\hline $24-1,87-90$ & 2.33 & - & 40.0 & - & 40.0 & 20.0 & - & - & - & - & - & - & - \\
\hline $24-3,71-73$ & 0.35 & - & 42.9 & - & 42.9 & - & - & - & - & 14.2 & - & - & .. \\
\hline $24-4,38-40$ & 0.14 & 2.2 & 32.6 & - & 8.7 & 15.2 & 4.3 & - & 17.4 & 17.4 & - & - & 2.2 \\
\hline $25-3,138-140$ & 0.29 & - & 13.0 & - & 61.0 & 13.0 & - & - & - & 13.0 & - & - & - \\
\hline $25-5,130-132$ & 0.35 & - & 23.5 & - & 32.5 & 14.7 & 2.9 & - & 17.6 & 8.8 & - & - & - \\
\hline $26-5,115-117$ & 0.53 & - & 6.7 & - & 86.6 & 6.7 & - & - & - & - & - & - & - \\
\hline $27-2,125-127$ & 0.59 & 24.1 & 13.9 & - & 31.0 & 31.0 & - & - & - & - & - & - & - \\
\hline $28-1,95-98$ & 0.66 & 4.8 & 4.8 & - & 61.8 & 23.8 & 4.8 & - & - & - & $\begin{array}{l}- \\
-\end{array}$ & - & - \\
\hline $28-2,52-54$ & 0.29 & - & 12.1 & - & 60.4 & 24.1 & - & - & - & - & 3.4 & - & - \\
\hline $29-1,121-124$ & 0.10 & 1.8 & 7.3 & - & 21.8 & 61.8 & - & - & - & - & 7.3 & - & - \\
\hline $29-2,109-111$ & 0.16 & 4.3 & 8.7 & - & 23.2 & 46.5 & - & - & 4.3 & 10.1 & - & - & 2.9 \\
\hline $30-2,10-12$ & 0.37 & 3.6 & 14.3 & - & 46.4 & 7.1 & 3.6 & - & 14.3 & 10.7 & - & - & - \\
\hline $30-5,5-8$ & 0.07 & - & 12.5 & - & 20.8 & 6.3 & 2.1 & - & 31.2 & 27.1 & - & - & - \\
\hline $31-1,84-86$ & 0.06 & - & 8.0 & - & 12.0 & 2.0 & 2.0 & - & 52.0 & 22.0 & - & - & 2.0 \\
\hline $31-3,74-77$ & 0.04 & - & 7.5 & - & 9.4 & 3.8 & 1.9 & - & 35.8 & 39.7 & - & - & 1.9 \\
\hline $32-1,104-105$ & 0.07 & - & 4.1 & - & 12.2 & 4.1 & 2.0 & - & 47.0 & 30.6 & - & - & - \\
\hline $440 \mathrm{~B}-10-3,14-16$ & 0.71 & 31.1 & 11.7 & - & 12.6 & 44.6 & - & - & - & - & - & - & - \\
\hline $53-1,3-5$ & 1.17 & 4.3 & 5.8 & - & 37.7 & 50.8 & - & - & 1.4 & - & - & - & - \\
\hline $63-3,43-45$ & 0.01 & - & 9.1 & - & 21.2 & 51.5 & 3.0 & - & 9.1 & 6.1 & - & - & - \\
\hline $441 \mathrm{~A}-5-2,82-84$ & 0.45 & - & 16.1 & - & 71.0 & 3.2 & - & - & 6.5 & 3.2 & - & - & - \\
\hline $5-3,46-48$ & 0.15 & - & 7.0 & - & 14.0 & 69.7 & 2.3 & - & 7.0 & - & - & - & - \\
\hline $6-1,125-127$ & 0.36 & 24.5 & 10.2 & - & 28.6 & 34.7 & 2.0 & - & - & - & - & - & - \\
\hline $6-2,20-22$ & 0.24 & 26.1 & 13.0 & - & - & 58.7 & - & - & - & 2.2 & - & - & - \\
\hline $14-1,110-114$ & 0.36 & - & 9.1 & - & 18.2 & 63.6 & - & - & - & 9.1 & - & - & - \\
\hline
\end{tabular}

${ }^{\mathrm{a}}$ Includes opaque minerals.

\section{CONSIDERATION}

The most striking feature of the assemblages in the Miocene to Pleistocene sediments is the high concentrations of pyroxene and hornblende, in contrast with the scantiness of zircon and garnet. This strongly suggests a volcanic source for these sediments.
Okada (in Ujiie et al., 1977), in a study of the lateCenozoic sediments in northwestern Hokkaido, discriminated four heavy-mineral suites: (1) augite-hypersthene-hornblende-glaucophane, (2) zircon-garnetaugite -diopside-hypersthene-hornblende-glaucophane, (3) augite-hypersthene-hornblende, and (4) zircon-tourmaline-garnet-augite-hornblende. 


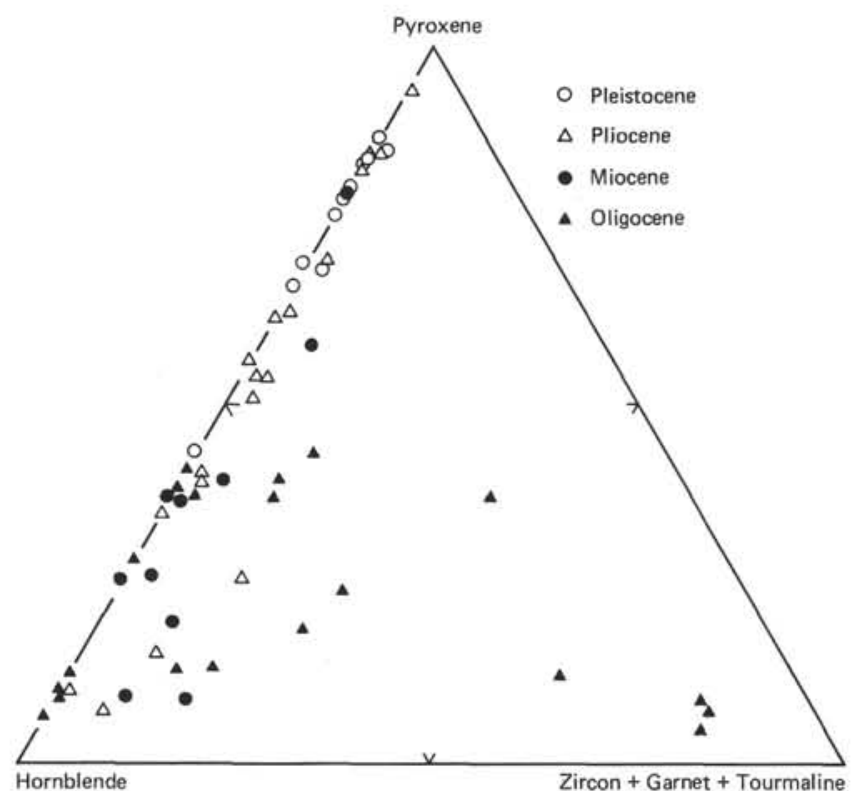

Figure 1. Ternary diagram for selected heavy-mineral end members.

Heavy-mineral assemblages in the present Miocene to Pleistocene samples are in harmony with these four suites excepting the disappearance of glaucophane, and they show, as Okada concluded, the predominance of volcanic clasts as source materials. The abundance of unstable mafic minerals and their unrounded and unbroken condition are attributed to short transportation from nearby source rocks. This also indicates active magmatism in an island arc during Neogene to Quaternary time.

The analytical results lead to the conclusion that volcanism must have been active in the northern Japanese Islands not only during the Miocene to Pleistocene, as has been verified by the land geology, but also during the Oligocene; this volcanism, although its intensity changed from time to time, supplied detritus to the Japan Trench. A predominance of hornblende and pyroxene characterizes the volcanic activity of the Oligocene to Miocene and the Pliocene to Pleistocene (Figure 2).

Another characteristic of these assemblages is the rather frequent appearance in the upper-Oligocene materials of zircon and garnet, which are index minerals for older sedimentary rocks, as is clear from Figure 1. The source area of the sedimentary clasts of the Oligocene samples is an important problem.

The shipboard scientists supposed a land area named the "Oyashio ancient landmass" to the east of the sites during the Oligocene, which subsided gradually during the Neogene. Judging from our finding that the heavymineral assemblages change between the Oligocene and the Neogene to Quaternary, we consider it possible that this landmass was the source area for the Oligocene sediments; however the details will have to be investigated further.

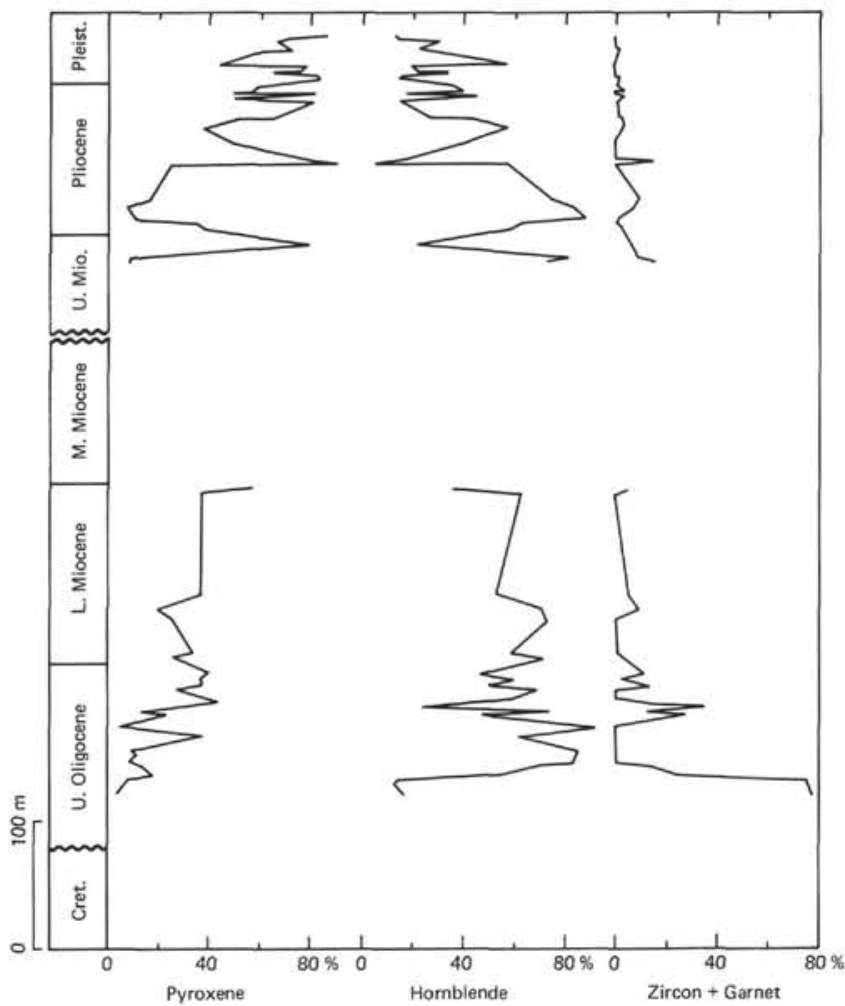

Figure 2. Variation in frequency of main heavy minerals with age.

The site reports for Leg 56 (this volume) describe a structural repetition of beds. It is impossible to divide our samples into groups based on heavy-mineral assemblages, because of their similar composition; consequently, we cannot elucidate this problem.

\section{CONCLUSIONS}

Pyroxene and hornblende, index minerals of volcanic rocks, are abundant in whole samples, particularly in those of the Miocene to Pleistocene. Zircon and garnet, which occur usually in sedimentary rocks, frequently appear in the Oligocene samples, although they are scarce in other samples.

From these results, we presume the existence of a sedimentary landmass near the trench as a source of the clasts during the Oligocene, in addition to the volcanic source.

\section{ACKNOWLEDGMENTS}

We express our sincere thanks to Prof. Noriyuki Nasu of the University of Tokyo and to Prof. Hakuyu Okada of Shizuoka University, who gave us the chance to study these sediments and valuable advice throughout the study. We are grateful to Prof. Tsugio Shuto and to Prof. Jyonosuke Ohara of Kyushu University for their critical reading of the manuscript. 


\section{REFERENCES}

Miki, T., 1972. Cretaceous-Tertiary unconformity in the western part of Amakusa-Shimoshima. Memoirs Faculty Sci., Kyushu University, 21, 217.

Poldervaart, A., 1955. Zircons in rocks. 1. Sedimentary rocks. Am. J. Sci., 253, 433.
Ujiie, H., Saito, T., Kent, D. V., Thompson, P. R., Okada, H., Klein, G. V., Koizumi, I., Harper, H. E., and Sato, T., 1977. Biostratigraphy, paleomagnetism and sedimentology of late Cenozoic sediments in northwestern Hokkaido, Japan. Bull. Nat. Sci. Museum, 3, 49.

\section{PLATE 1}

Photomicrographs of Heavy Minerals from Sediments

of the Japan Trench Transect

hy, hypersthene; ho, hornblende; ep, epidote

Figure 1 Sample 434-1-1, 121-123 cm.

Figure 2 Sample 434-15-1, 32-34 cm.

Figure 3 Sample 434-15-2, 42-44 cm.

Figure 4 Sample 434-25-1, 43-45 cm.

Figure 5 Sample 435-7-3, 70-71 cm.

Figure 6 Sample 435-9-3, 86-88 cm. 
PLATE 1
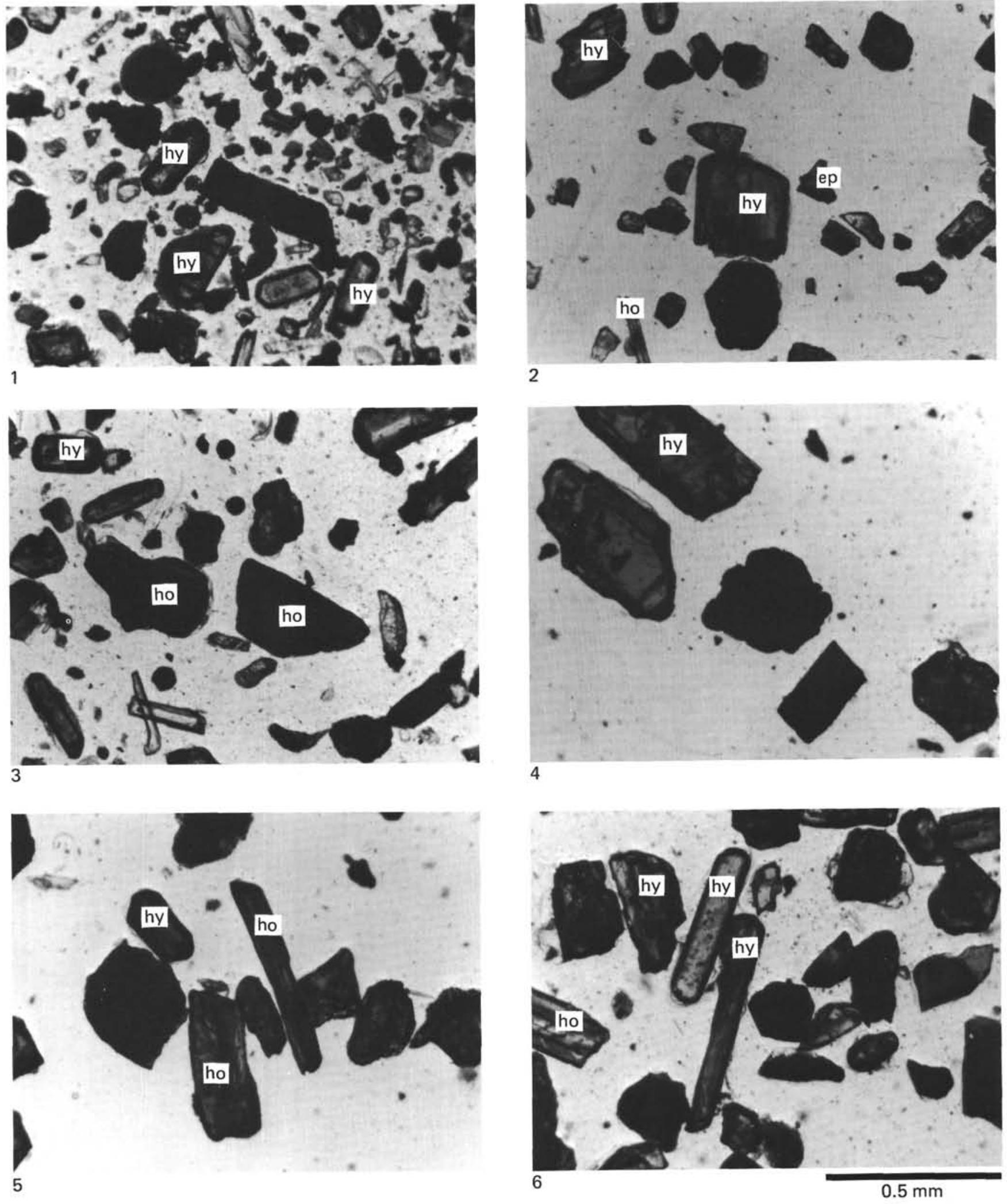
PLATE 2

Photomicrographs of Heavy Minerals from Sediments of the Japan Trench Transect hy, hypersthene; ho, hornblende;

z, zircon; gt, garnet; g, clauconite

Figure 1 Sample 438-1-1, 17-19 cm.

Figure 2 Sample 438-1-2, 66-68 cm.

Figure 3 Sample 438-8-3, 16-18 cm.

Figure 4 Sample 438A-42-3, 115-117 cm.

Figure 5 Sample 438B-9-1, 61-63 cm.

Figure 6 Sample 439-31-3, 74-77 cm. 
PLATE 2
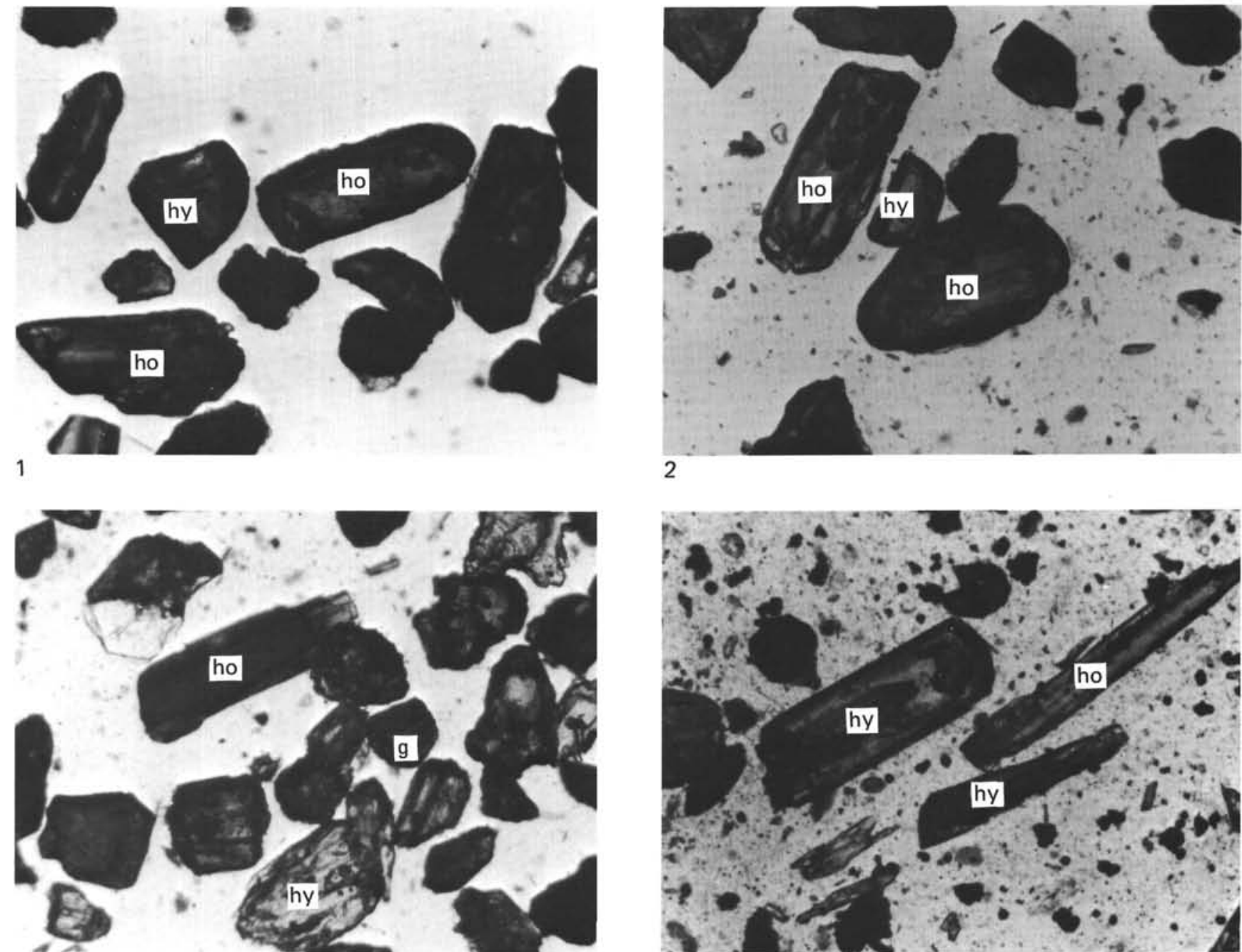
3
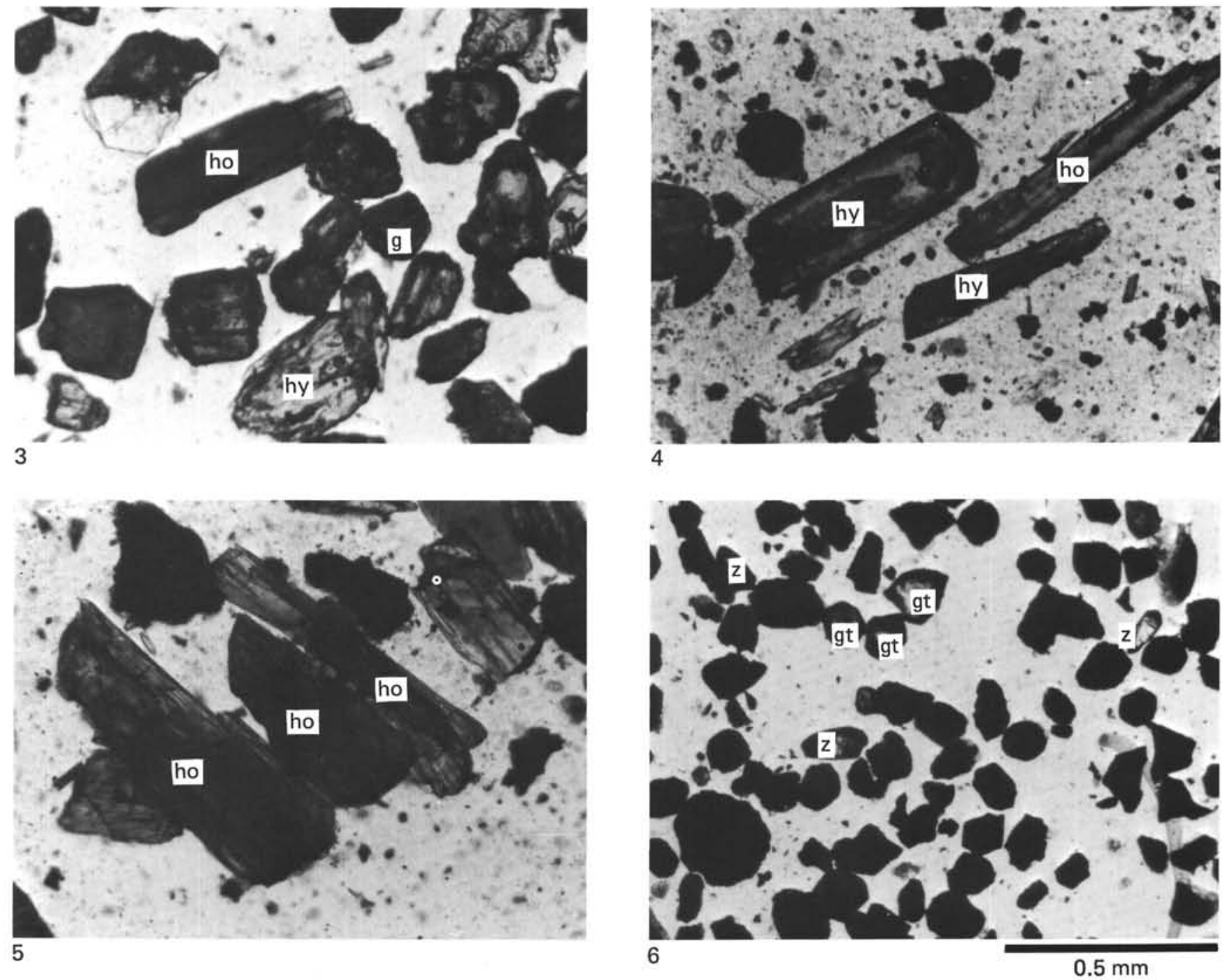